\title{
Thermus oshimai sp. nov., Isolated from Hot Springs in Portugal, Iceland, and the Azores, and Comment on the Concept of a Limited Geographical Distribution of Thermus Species
}

\author{
RALPH A. D. WILLIAMS, ${ }^{*}$ KELVIN E. SMITH, SIMON G. WELCH, AND JANICE MICALLEF \\ Department of Biochemistry, Queen Mary and Westfield College, \\ London, E1 4NS, United Kingdom
}

\begin{abstract}
We examined aerobic, thermophilic, gram-negative bacteria that were isolated from hot springs in Portugal and were identified as Thermus strains and placed in phenetic groups on the basis of their phenotypic characteristics. We determined the composition of the peptidoglycan, identified the respiratory quinones, and determined the mean base composition of the DNA, and the levels of DNA-DNA homology were determined by both the filter hybridization and reassociation rate methods. Thermus aquaticus, Thermus brockianus, and Thermus filiformis were not detected in this collection of organisms, although three Thermus thermophilus strains were identified. We propose that the isolates that belonged to phenetic clusters $\mathbf{E}$ and $\mathbf{F}$ are members of a new species, Thermus oshimai; the type strain of T. oshimai is strain SPS17.
\end{abstract}

Members of the thermophilic genus Thermus and its type species, Thermus aquaticus, are aerobic, nonsporulating, heterotrophic rods that have optimum $\mathrm{pH}$ values between 7.0 and 8.0 and an optimum temperature of $70^{\circ} \mathrm{C}(4)$. The Gram reaction is negative, and the cell wall has an outer layer that balloons out from the inner peptidoglycan at regular intervals $(3,49)$. Thermus strains have been isolated from hot springs and other thermal environments in the United States $(2,4,5$, $27,35,44,53)$, Iceland $(1,7,18,21-23,32,42)$, Belgium (8), Britain (31), Portugal $(26,39,47,48)$, the Czech Republic (34), Germany (15), the former USSR $(24,25)$, Japan $(28,29,37,45$, 46), New Zealand (16, 17), Thailand (20), and Kenya (51). Thermus isolates are usually yellow pigmented because they contain carotenoids, but colorless strains have been isolated from sources sheltered from light $(2,22,31,35,39,44)$. The Thermus species that have been described previously are Thermus aquaticus, Thermus filiformis, Thermus thermophilus, Thermus scotoductus, Thermus brockianus, and the red-pigmented organism Thermus ruber. Thermus filiformis has a unique filamentous habit and was validly described despite the fact that only a single isolate was available (17); however, several nonfilamentous isolates from New Zealand exhibit high levels of
DNA-DNA homology with this strain (11). Strain $\mathrm{HB}^{\mathrm{T}}$ (T = type strain) was isolated in Japan (28) and was validly described as a Thermus thermophilus strain (29). Although the name Thermus thermophilus was not included in the Approved Lists of Bacterial Names (43), it has been proposed (26, 49-53) that this taxon should be reestablished and should include the invalid species "Thermus flavus" (37) and "Thermus caldophilus" (45). Recently, pale strain X1 (35), which turns brownish in older cultures, and similar Icelandic isolates were described as members of the species Thermus scotoductus (22). The species Thermus brockianus, which coexists with Thermus aquaticus in the hot springs of Yellowstone National Park, was also described recently (53). Thermus ruber, which contains red carotenoids and grows optimally at $60^{\circ} \mathrm{C}$, has been validly described $(24,25)$ but is easily distinguished from the other species mentioned above phenotypically and by its lower optimum temperature; this organism exhibits very low levels of DNADNA homology with other Thermus species (42). Thermus silvanus and Thermus chliarophilus are species that are related to Thermus ruber and have low optimum growth temperatures $\left(55^{\circ}\right.$ and $50^{\circ} \mathrm{C}$, respectively) (47).

For a valid taxonomy to be established, large collections of

TABLE 1. Sources of the Thermus isolates used

\begin{tabular}{|c|c|c|}
\hline Strain(s) & Other designation(s) & Source \\
\hline Thermus aquaticus $\mathrm{YT}^{\mathrm{T}}$ & ATCC $25104^{\mathrm{T}}$, DSM $625^{\mathrm{T}}$, NCIB $11243^{\mathrm{T}}$ & $\mathrm{ATCC}^{\alpha}$ \\
\hline Thermus filiformis Wai33A1 ${ }^{\mathrm{T}}$ & ATCC $42380^{\mathrm{T}}$, NCIB $12588^{\mathrm{T}}$ & ATCC \\
\hline Thermus brockianus ${\text { YS } 38^{\mathrm{T}}}$ & NCIB 12588 & R. J. Sharp \\
\hline Thermus thermophilus $\mathrm{HB} 8^{\mathrm{T}}$ & ATCC $27624^{\mathrm{T}}$, DSM $579^{\mathrm{T}}$, NCIB $11244^{\mathrm{T}}$ & T. Oshima \\
\hline Thermus thermophilus B & NCIB 11247 & R. A. D. Williams \\
\hline Thermus thermophilus IB21 & & G. Alfredsson \\
\hline Thermus scotoductus X1 & & R. Ramaley \\
\hline $\begin{array}{l}\text { Thermus oshimai SPS7, SPS8, SPS10, SPS11, SPS12, } \\
\text { SPS14, SPS17 }{ }^{\mathrm{T}} \text {, and SPS18 }\end{array}$ & & M. S. da Costa (Sao Pedro do Sul) \\
\hline Thermus oshimai $\mathrm{AC} 2, \mathrm{AS} 1, \mathrm{AS} 2, \mathrm{AS} 3$, and $\mathrm{CB} 1$ & & M. S. da Costa (Azores) \\
\hline Thermus oshimai JK66 and JK91 & & J. Kristjansson (Iceland) \\
\hline
\end{tabular}

${ }^{a}$ ATCC, American Type Culture Collection, Rockville, Md.

\footnotetext{
* Corresponding author. Mailing address: Department of Biochemistry, Queen Mary and Westfield College, Mile End Road, London E1 4NS, United Kingdom. Phone: 0171-982-6337. Fax: 0181-983-0531. Electronic mail address: r.a.d.williams@qmw.ac.uk.
} 
TABLE 3. Levels of DNA-DNA homology of Thermus strains as determined by spectrometry

\begin{tabular}{|c|c|c|c|c|c|c|c|c|c|c|c|c|}
\hline \multirow{2}{*}{ Strain } & \multicolumn{12}{|c|}{ \% DNA-DNA homology with: } \\
\hline & $\overline{\mathrm{YT}^{\mathrm{T}}}$ & Wai33A1 $^{\mathrm{T}}$ & $\mathrm{HB}^{\mathrm{T}}$ & $\mathrm{YS} 38^{\mathrm{T}}$ & $\mathrm{X} 1$ & SPS11 & SPS14 & SPS17 $7^{\mathrm{T}}$ & JK66 & JK90 & Vi7a & $\overline{\mathrm{Vi13}}$ \\
\hline Thermus aquaticus $\mathrm{YT}^{\mathrm{T}}$ & 100 & 35 & 42 & 41 & 52 & & & 38 & & 50 & 42 & 50 \\
\hline Thermus filiformis Wai $33 \mathrm{~A} 1^{\mathrm{T}}$ & & 100 & 36 & 21 & 52 & & & 34 & & 53 & 40 & 41 \\
\hline Thermus thermophilus $\mathrm{HB}^{\mathrm{T}}$ & & & 100 & 36 & & & & 35 & & 22 & 29 & 42 \\
\hline Thermus brockianus YS38 ${ }^{\mathrm{T}}$ & & & & 100 & & & & 40 & & & 36 & \\
\hline Thermus scotoductus X1 & & & & & 100 & 33 & 39 & & 43 & 51 & & \\
\hline \multicolumn{13}{|c|}{ Phenotypic cluster $\mathrm{E}$ and $\mathrm{F}$ strains ${ }^{a}$} \\
\hline SPS11 & & & & & & 100 & 80 & 80 & 82 & & & \\
\hline SPS14 & & & & & & & 100 & 82 & 69 & 78 & 35 & \\
\hline SPS $17^{\mathrm{T}}$ & & & & & & & & 100 & 69 & 81 & 31 & \\
\hline JK66 & & & & & & & & & 100 & 70 & & \\
\hline JK90 & & & & & & & & & & 100 & & 41 \\
\hline \multicolumn{13}{|c|}{ Phenotypic cluster A through D strains ${ }^{a}$} \\
\hline Vi7a & & & & & & & & & & & 100 & 97 \\
\hline Vi13 & & & & & & & & & & & & 100 \\
\hline
\end{tabular}

a Phenotypic clusters as defined by Santos et al. (39).

isolates must be examined in detail, and data for significant cell constituents, particularly the nucleic acids, must be included. In this paper we present DNA-DNA homology data, $16 \mathrm{~S}$ ribosomal DNA (rDNA) sequence data $(10,40)$, and phenotypic property data (39) for a collection of strains: our data support creation of a new species, Thermus oshimai. Strain SPS17 is the type strain of this new species.

\section{MATERIALS AND METHODS}

Strains and culture conditions. The Thermus strains which we used and their sources are shown in Table 1 . Cells were grown at $65^{\circ} \mathrm{C}$, harvested, and stored at $-20^{\circ} \mathrm{C}$ as described previously $(42,53)$.

Respiratory quinone. A cell paste was freeze-dried, extracted, and chromatographed on preparative Keiselgel $60 \mathrm{~F}$ thin-layer plates. Individual quinones were eluted from the plates and then rechromatographed on $\operatorname{RP1} 18_{\mathrm{F} 254}$ plates $(6,53)$ to determine the lengths of the side chains. The $R_{f}$ values of the quinones in extracts of Thermus strains were compared with the $R_{f}$ values of the menaquinones of Bacillus stearothermophilus and Thermus aquaticus $\mathrm{YT}^{\mathrm{T}}{ }^{\mathrm{T}}$. UV absorption spectra of isooctane extracts from the preparative plates were recorded at wavelengths between 230 and $350 \mathrm{~nm}$.

Peptidoglycan preparation and analysis. Cells were extracted by the rapid peptidoglycan preparation method (41) and then were hydrolyzed with $4 \mathrm{M} \mathrm{HCl}$; the hydrolysate was separated by thin-layer chromatography on cellulose plates and tested for the presence of ornithine (13) and the absence of diaminopimelic acid (36) as described previously (53). The amino acids and amino sugars in some samples were analyzed quantitatively with an LKB model 4000 amino acid analyzer.

DNA purification and mean base composition. Cells were lysed and DNA was purified as described previously $(38,42,53)$, and the mean base composition was determined by thermal denaturation in $0.1 \times$ standard saline citrate (SSC; $1 \times$ SSC is $0.15 \mathrm{M} \mathrm{NaCl}$ plus $0.015 \mathrm{M}$ sodium citrate) with either a Gilford Response spectrophotometer or a Pye-Unicam model 8800 spectrophotometer equipped with a model SPX876 programmed heating accessory. The mean base composition was calculated by using reference DNA from Escherichia coli DSM 2840 $(\mathrm{G}+\mathrm{C}$ content, $52 \mathrm{~mol} \%)$ and the following formula: $\mathrm{G}+\mathrm{C}$ content $=52+$ $2.08\left(T_{m}-T_{m}\right.$ of DSM 2840 DNA) (30), where $T_{m}$ is the melting temperature.

DNA-DNA homology. Hybridization of sheared fragments of $\left[{ }^{3} \mathrm{H}\right]$ DNA with single-stranded DNA bound to 5-mm nitrocellulose discs was performed as described previously $(42,53)$. Levels of DNA-DNA homology were also obtained by determining the reassociation rates of sheared fragments of denatured DNA samples $(9,12)$ under optimum conditions with a Gilford Response spectrophotometer (53). The final sodium concentration used for renaturation $(0.515 \mathrm{M})$ gave an estimated $T_{m}$ of $101^{\circ} \mathrm{C}$ when the following equation was used: $T_{m}=0.41$ $\times \mathrm{G}+\mathrm{C}$ content $+78.7+13.3 \log \left[\mathrm{Na}^{+}\right](9)$. The renaturation temperature used was $25^{\circ} \mathrm{C}$ below the estimated $T_{m}$, and $33 \mu \mathrm{l}$ of $5 \mathrm{M}$ sodium chloride at the same temperature was rapidly mixed into each cuvette. The decrease in $A_{260}$ at this temperature was monitored for $30 \mathrm{~min}$.

\section{RESULTS AND DISCUSSION}

The mean base compositions of the DNAs of the 30 strains examined ranged from 60 to $66 \mathrm{~mol} \% \mathrm{G}+\mathrm{C}$, which is consis- tent with the values obtained for other species belonging to the genus Thermus. The respiratory quinone was determined to be a menaquinone on the basis of its $R_{f}$ value on the preparative thin-layer plate examined and its UV absorption spectrum. The $R_{f}$ value for the menaquinones of all strains on a reversephase plate was identical to the $R_{f}$ value for strain $\mathrm{YT}^{\mathrm{T}}{ }^{\mathrm{T}}$. Thus, menaquinone 8 was identified as the menaquinone in all strains of the new species, including type strain SPS17.

A qualitative analysis revealed that ornithine was the major dibasic amino acid in the peptidoglycan of the new species, as it is in all other Thermus strains that have been tested $(15,33)$. Lysine was present as a minor substituent.

Strains that were identified in a previous phenotypic study as members of clusters A to D and were isolated by M. S. da Costa from hot springs at Caldas da Vizela (Vi strains) in mainland Portugal and similar isolates from Sao Miguel Island form a homogeneous DNA homology group and have been placed in Thermus scotoductus (48). Clusters E and F that were identified in the same numerical analysis of phenotypic properties (39) comprise strains that were isolated by M. S. da Costa from hot springs at Sao Pedro do Sul in mainland Portugal (SPS strains) and Sao Miguel Island in the Azores. These two phenotypic clusters belong to one distinct DNA-DNA homology group (Tables 2 and 3), and members of these clusters exhibit high levels of homology with other members of the group but low levels of homology with Thermus aquaticus, Thermus brockianus, Thermus thermophilus, Thermus scotoductus, and Thermus filiformis. This agreement between the results of a numerical taxonomic analysis on the one hand and chemical and genetic characteristics of the cells on the other supports the hypothesis that the new species described in this paper is valid. Two strains isolated by $\mathbf{J}$. Kristjansson in Iceland (strains JK66 and JK91) also appear to belong to the same genospecies. Although this species occurs in the Azores and in Iceland, as well as at Sao Pedro do Sul in Portugal, another species appears to be the predominant organism at Vizela, which is only about $75 \mathrm{~km}$ from Sao Pedro do Sul. This indicates that factors other than mere geographical distance may contribute to the colonization of hot springs by different Thermus species.

The cataloging of oligonucleotides derived from hydrolysis of $16 \mathrm{~S}$ rRNA revealed that there is a distinct, if remote, relationship between Thermus aquaticus and Thermus ruber on the one hand and the genus Deinococcus on the other (15). Alignment of the 16S rRNA gene sequence of Thermus thermophilus 


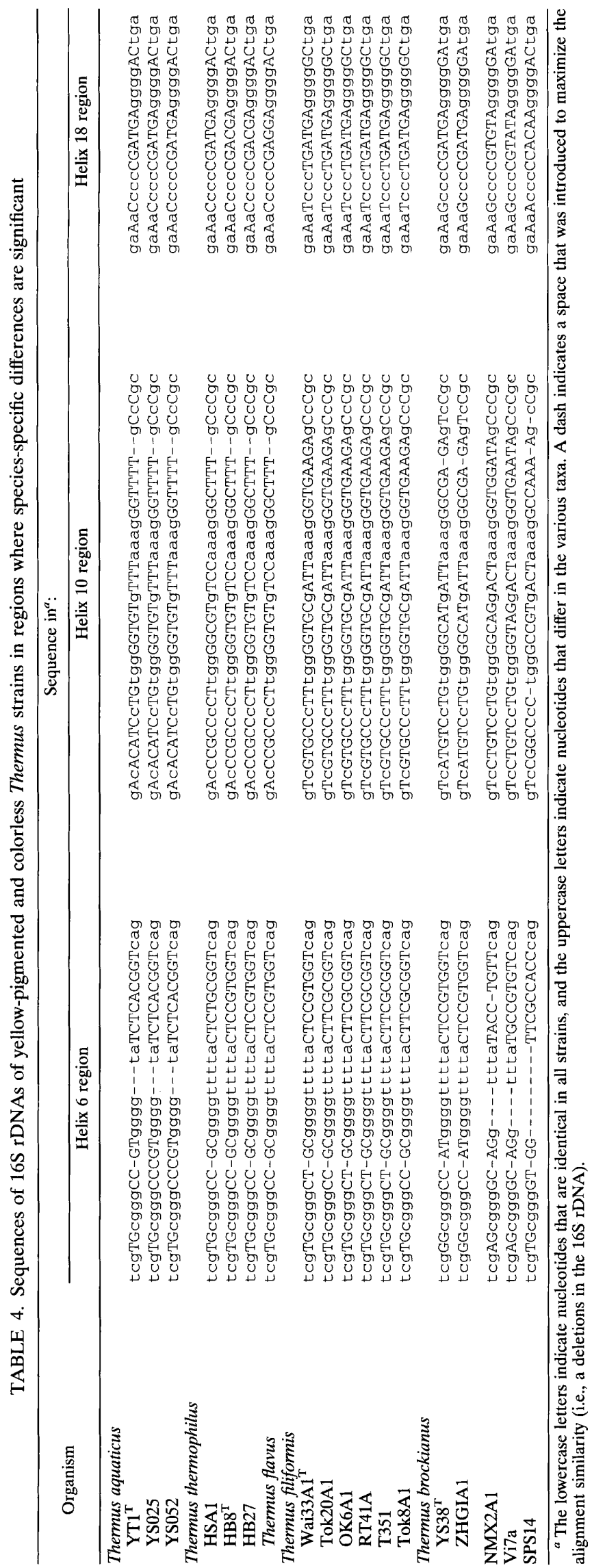

$\mathrm{HB}^{\mathrm{T}}$ (14) with other $16 \mathrm{~S}$ rRNA sequences revealed that the genus Thermus is related to the green nonsulfur bacteria, the second deepest bacterial branch point after the Thermotoga maritima branch point. Many $16 \mathrm{~S}$ rRNA and $16 \mathrm{~S}$ rDNA sequences of Thermus strains are now available $(10,40,52)$ (GenBank accession numbers L09660 to L09672). The sequences of the 16S rDNA genes of Thermus ruber, Thermus brockianus YS38 ${ }^{\mathrm{T}}$, and strains Vi7 and SPS14 (10) confirmed the conclusion based on DNA-DNA homology data that the yellow-pigmented Thermus strains are closely related to each other but not to Thermus ruber (42). The lower "thermophilic bias" that was evident in the sequence of the Thermus ruber gene, which was associated with the lower growth temperature of this organism compared with the yellow-pigmented strains, was important in confirming the relationship between the thermophilic genus Thermus and the mesophilic genus Deinococcus (10).

- The sequences of the 16S rDNA genes of Thermus aquaticus $\mathrm{YT}^{\mathrm{T}}$, "Thermus flavus" AT62, Thermus sp. strains HSA1, OK6A1, Rt41A, T351, Tok8A1, Tok20A1, and ZHGIA1, Thermus filiformis Wai33A $1^{\mathrm{T}}$, and Thermus ruber were determined by Saul et al. (40) and have been deposited in the GenBank data base. When these sequences were aligned with those of Thermus aquaticus YS25 and YS52 (unpublished sequences determined at the Deutsche Sammlung von Mikroorganismen for R. J. Sharp), Thermus thermophilus $\mathrm{HB}^{\mathrm{T}}(14,15)$ and HB27 (GenBank accession number L09659), Thermus brockianus YS38 ${ }^{\mathrm{T}}$, and strains Vi7 and $\operatorname{SPS}_{17} 7^{\mathrm{T}}(10)$, it was found that the regions that include helices 6,10 , and 18 (Table 4) vary from species to species. The variations show that 16S rRNA sequences may be used to identify species. These data support the hypothesis that the geographical distribution of Thermus species may not be as restricted as has been thought. The sequence of strain HSA1 (isolated in the South Island of New Zealand [16]) is very similar to the sequences of Thermus thermophilus $\mathrm{HB}^{\mathrm{T}}$ and "Thermus flavus" from Japan. Thermus thermophilus strains are known to occur in widely separated areas, including Icelandic terrestrial (47) and marine hot springs (23) and Sao Miguel in the Azores. The 16S rDNA sequence of ZHGIA1, which was isolated in Iceland (18), indicates that this strain belongs to the species Thermus brockianus, which was found (53) among strains obtained from Yellowstone National Park in the United States (27). Similarly, the sequence of the 16S rDNA gene of isolate NMX2A1 from New Mexico (19) indicates that this organism is similar to the Vizela strains from Portugal and Sao Miguel Island in the Azores, which themselves belong to a species whose strains have been isolated from sources in Britain, the United States, and Iceland. The concept of a circumscribed geographical distribution of Thermus species may therefore be more apparent than real. Clearly, there may be unknown chemical and physical reasons why a particular species may thrive in one spring but not in another. It seems likely that the use of $16 \mathrm{~S}$ rDNA sequences and species-specific probes for the 16S rDNA gene with large collections of isolates should throw light on the true distribution of Thermus species and also should allow the occurrence of these organisms to be correlated with the results of physical and chemical analyses of hot spring waters. The $16 \mathrm{~S}$ rDNA sequences currently available for Thermus species have recently been tabulated to assist in the design of species-specific probes (52).

Description of Thermus oshimai sp. nov. Thermus oshimai (osh'i.ma.i. N.L. adj. oshimai, referring to T. Oshima, a prolific researcher who has studied the molecular biology of the genus Thermus). Aerobic, heterotrophic, thermophilic short rods that are gram negative. Thermus oshimai forms a yellow pigment 
like Thermus brockianus, but does not exhibit the distinctive spreading colonial morphology of Thermus brockianus on tryptone-yeast extract plates at $70^{\circ} \mathrm{C}$. Peptidoglycan has ornithine cross-links with glycine in the interpeptide bridge; the respiratory quinone is menaquinone 8 ; and the DNA G+C content is 62 to $65 \mathrm{~mol} \%$ (63 mol\% in SPS17). More than $85 \%$ of the strains grow anaerobically in the presence of nitrate and form nitrite (39). Most strains hydrolyze fibrin, casein, and hideazure in plate assays, and most strains grow on glutamate and asparagine, fructose, mannose, and galactose. All strains grow on sucrose, maltose, and trehalose. Unlike the strains of the four other phenetic groups (39), Thermus oshimai strains grow on lactose (and form $\beta$-galactosidase) and on melibiose (and form $\alpha$-galactosidase). About one-half of the strains grow on glucose. The type strain is strain SPS17, which was isolated by M. S. da Costa from a sample obtained from Sao Pedro do Sul, Portugal (39); this strain has been deposited in the National Collection of Industrial and Marine Bacteria as strain NCIMB 13400 .

\section{ACKNOWLEDGMENTS}

We are grateful to Gudni Alfredsson, Milton da Costa, Jakob Kristjansson, Tairo Oshima, Robert Ramaley, and Richard Sharp for gifts of strains and to Martin Embley for help in determining the 16S rDNA sequence and aligning the sequences.

\section{REFERENCES}

1. Alfredsson, G. A., S. Baldursson, and J. K. Kristjansson. 1985. Nutritional diversity among Thermus spp. isolated from Icelandic hot springs. Syst. Appl. Microbiol. 6:308-311.

2. Brock, T. D., and K. L. Boylen. 1973. Presence of thermophilic bacteria in laundry and domestic hot-water heaters. Appl. Microbiol. 25:72-76.

3. Brock, T. D., and M. R. Edwards. 1970. Fine structure of Thermus aquaticus, an extreme thermophile. J. Bacteriol. 104:509-517.

4. Brock, T. D., and H. Freeze. 1969. Thermus aquaticus gen. n. and sp.n., a nonsporulating extreme thermophile. J. Bacteriol. 98:289-297.

5. Brock, T. D., and I. Yoder. 1971. Thermal pollution of a small river by a large university. Bacteriological studies. Proc. Indiana Acad. Sci. 80:183-188.

6. Collins, M. D., and D. Jones. 1981 . Distribution of isoprene quinone structural types in bacteria and their taxonomic implications. Microbiol. Rev. 45: 316-354

7. Cometta, S., B. Sonnleitner, W. Sidler, and A. Fiechter. 1982. Population distribution of aerobic extremely thermophilic microorganisms in an Icelandic natural hot spring. Eur. J. Appl. Microbiol. Biotechnol. 16:151-156.

8. Degryse, E., N. Glansdorfi, and A. Pierard. 1978. A comparative analysis of extreme thermophilic bacteria belonging to the genus Thermus. Arch. Microbiol. 117:189-196.

9. De Ley, J., H. Cattoir, and A. Reynaerts. 1970. The quantitative measurement of DNA hybridization from renaturation rates. Eur. J. Biochem. 12: 133-142.

10. Embley, T. M., R. H. Thomas, and R. A. D. Williams. 1993. Reduced thermophilic bias in the 16S rDNA sequence from Thermus ruber provides further support for a relationship between Thermus and Deinococcus. Syst. Appl. Microbiol. 16:25-29.

11. Georganta, G., K. E. Smith, and R. A. D. Williams. 1993. DNA:DNA homology and cellular components of Thermus filiformis and other strains of Thermus from New Zealand hot springs. FEMS Microbiol. Lett. 107:145150.

12. Gillis, M., J. De Ley, and M. De Cleene. 1970. The determination of molecular weight of bacterial genome DNA from renaturation rates. Eur. J. Biochem. 12:143-153.

13. Hardy, T. L., D. O. Holland, and J. H. C. Nayler. 1955. One-phase solvent systems for the separation of amino acids. Anal. Chem. 27:971-973.

14. Hartmann, R. K., J. Wolters, B. Kroger, S. Schultze, T. Specht, and V. A. Erdmann. 1989. Does Thermus represent another deep eubacterial branching? Syst. Appl. Microbiol. 11:243-249.

15. Hensel, R., W. Demharter, O. Kandler, R. M. Kroppenstedt, and E. Stackebrandt. 1986. Chemotaxonomic and molecular-genetic studies of the genus Thermus: evidence for a phylogenetic relationship of Thermus aquaticus and Thermus ruber to the genus Deinococcus. Int. J. Syst. Bacteriol. 36:444-453.

16. Hudson, J. A., H. W. Morgan, and R. M. Daniel. 1986. A numerical classification of some Thermus isolates. J. Gen. Microbiol. 132:531-540.

17. Hudson, J. A., H. W. Morgan, and R. M. Daniel. 1987. Thermus filiformis sp. nov., a filamentous caldoactive bacterium. Int. J. Syst. Bacteriol. 37: $431-436$.
18. Hudson, J. A., H. W. Morgan, and R. M. Daniel. 1987. Numerical classification of some Thermus isolates from Icelandic hot springs. Syst. Appl. Microbiol. 9:218-223.

19. Hudson, J. A., H. W. Morgan, and R. M. Daniel. 1989. Numerical classification of some Thermus isolates from globally distributed hot springs. Syst. Appl. Microbiol. 11:250-256.

20. Kanasawud, P., S. Teeyapan, S. Lumyong, O. Holst, and B. Mattiasson. 1992. Thermus $2 \mathrm{~S}$ from Thai hot springs: isolation and immobilization. World J. Microbiol. Biotechnol. 8:137-140.

21. Kristjansson, J. K., and G. A. Alfredsson. 1983. Distribution of Thermus spp. in Icelandic hot springs and a thermal gradient. Appl. Environ. Microbiol. 45:1785-1789.

22. Kristjansson, J. K., S. Hjorleifsdottir, V. T. Marteinsson, and G. A. Alfredsson. 1994. Thermus scotoductus, sp. nov., a pigment-producing thermophilic bacterium from hot tap water in Iceland and including Thermus sp. X1. Syst. Appl. Microbiol. 17:44-50.

23. Kristjansson, J. K., G. O. Hreggvidsson, and G. A. Alfredsson. 1986. Isolation of halotolerant Thermus spp. from submarine hot springs in Iceland. Appl. Environ. Microbiol. 52:1313-1316.

24. Loginova, L. G., and L. A. Egorova. 1976. An obligately thermophilic bacterium Thermus nuber from hot springs in Kamchatka. Microbiology (Engl. Trans. Mikrobiologiya) 44:593-597.

25. Loginova, L. G., L. A. Egorova, R. S. Golovacheva, and L. M. Seregina. 1984. Thermus nuber sp. nov. Int. J. Syst. Bacteriol. 34:498-499.

26. Maniaia, C. M., B. Hoste, M. C. Gutierrez, M. Gillis, A. Ventosa, K. Kersters, and M. S. da Costa. 1994. Halotolerant Thermus strains from marine and terrestrial hot springs belong to Thermus thermophilus (ex Oshima and Imahori, 1974) nom. rev. emend. Syst. Appl. Microbiol. 17:526-532.

27. Munster, M. J., A. P. Munster, J. R. Woodrow, and R. J. Sharp. 1986. Isolation and preliminary taxonomic studies of Thermus strains isolated from Yellowstone National Park, USA. J. Gen. Microbiol. 132:1677-1683.

28. Oshima, T., and K. Imahori. 1971. Isolation of an extreme thermophile and thermostability of its transfer ribonucleic acid and ribosomes. J. Gen. Appl. Microbiol. 17:513-517.

29. Oshima, T., and K. Imahori. 1974. Description of Thermus thermophilus (Yoshida and Oshima) comb. nov., a nonsporulating thermophilic bacterium from a Japanese thermal spa. Int. J. Syst. Bacteriol. 24:102-112.

30. Owen, R. J., and L. R. Hill. 1979. The estimation of base composition, base pairing and genome sizes of bacterial DNA. Soc. Appl. Bacteriol. Tech. Ser. 14:277-296.

31. Pask-Hughes, R., and R. A. D. Williams. 1975. Extremely thermophilic gram-negative bacteria from hot tap water. J. Gen. Microbiol. 88:321-328.

32. Pask-Hughes, R. A., and R. A. D. Williams. 1977. Yellow-pigmented strains of Thermus spp. from Icelandic hot springs. J. Gen. Microbiol. 102:375-383.

33. Pask-Hughes, R. A., and R. A. D. Williams. 1978. Cell envelope components of strains belonging to the genus Thermus. J. Gen. Microbiol. 107:65-72.

34. Peckova, M. 1991. Properties of a hyperthermophilic bacterium (Thermus sp.) isolated from a Carlsbad spring. Folia Microbiol. 36:515-521.

35. Ramaley, R. F., and J. Hixson. 1970. Isolation of a nonpigmented, thermophilic bacterium similar to Thermus aquaticus. J. Bacteriol. 103:527-528.

36. Rhuland, L. E., E. Work, R. F. Denman, and D. S. Hoare. 1955. The behavior of isomers of $\alpha$-e-diaminopimelic acid on paper chromatograms. J. Am. Chem. Soc. 77:4844-4846.

37. Saiki, T., R. Kimura, and K. Arima. 1972. Isolation and characterization of extremely thermophilic bacteria from hot springs. Agric. Biol. Chem. 36: 2357-2366.

38. Sambrook, J., E. F. Fritsch, and T. Maniatis. 1989. Molecular cloning: a laboratory manual, 2nd ed. Cold Spring Harbor Press, Cold Spring Harbor, N.Y.

39. Santos, M. A., R. A. D. Williams, and M. S. da Costa. 1990. Numerical taxonomy of Thermus isolates from hot springs in Portugal. Syst. Appl. Microbiol. 12:310-315.

40. Saul, D. J., A. G. Rodrigo, R. A. Reeves, L. C. Williams, K. M. Borges, H. W. Morgan, and P. L. Bergquist. 1993. Phylogeny of twenty Thermus isolates constructed from 16S rRNA gene sequence data. Int. J. Syst. Bacteriol. 43: 754-760.

41. Schleifer, K. H., and O. Kandler. 1972. Peptidoglycan types of bacteriai cell walls and their taxonomic implications. Bacteriol. Rev. 36:245-292.

42. Sharp, R. J., and R. A. D. Williams. 1988. Properties of Thermus nuber strains isolated from Icelandic hot springs and DNA-DNA homology of Thermus ruber and Thermus aquaticus. Appl. Environ. Microbiol. 54:2049-2053.

43. Skerman, V. B. D., V. McGowan, and P. H. A. Sneath (ed.). 1980. Approved lists of bacterial names. Int. J. Syst. Bacteriol. 30:225-420.

44. Stramer, S. L., and M. J. Starzyk. 1981. The occurrence and survival of Thermus aquaticus. Microbios 32:99-110.

45. Taguchi, H., M. Yamashita, H. Matsuzawa, and T. Ohta. 1982. Heat stable and fructose 1,6-biphosphate activated L-lactate dehydrogenase from an extremely thermophilic bacterium. J. Biochem. 91:1343-1348.

46. Takase, M., and K. Horikoshi. 1989. Purification and properties of a $\beta$-glucosidase from Thermus sp. Z-1. Agric. Biol. Chem. 53:559-560.

47. Tenreiro, S., M. F. Nobre, and M. S. da Costa. 1995. Thermus silvanus sp. nov. and Thermus chliarophilus sp. nov., two new species related to Thermus 
ruber but with lower growth temperatures. Int. J. Syst. Bacteriol. 45:633-639.

48. Tenreiro, S., M. F. Nobre, B. Hoste, M. Gillis, J. K. Kristjansson, and M. S. da Costa. 1995. DNA:DNA hybridization and chemotaxonomic study of Thermus scotoductus. Res. Microbiol. 146:315-324.

49. Williams, R. A. D. 1975 . Caldoactive and thermophilic bacteria and their thermostable proteins. Sci. Prog. 62:373-393.

50. Williams, R. A. D. 1989. Biochemical taxonomy of the genus Thermus, $\mathrm{p}$ 82-97. In M. S. da Costa, J. C. Duarte, and R. A. D. Williams (ed.) Microbiology of extreme environments and its potential for biotechnology. Elsevier, London.

51. Williams, R. A. D., and M. S. da Costa. 1992. The genus Thermus and related microorganisms, p. 3745-3753. In A. Balows, H. G. Truper, M. Dworkin, W. Harder, and K.-H. Schleifer (ed.), The prokaryotes. A handbook on the biology of bacteria: ecophysiology, isolation, identification, applications. Springer-Verlag, New York.

52. Williams, R. A. D., and R. J. Sharp. 1995. The taxonomy and identification of Thermus, p. 1-42. In Thermus species: a biotechnology handbook. Plenum Press, New York.

53. Williams, R. A. D., K. E. Smith, S. G. Welch, J. Micallef, and R. J. Sharp. 1995. DNA Relatedness of Thermus strains, description of Thermus brockianus sp. nov. and proposal to reestablish Thermus thermophilus (Oshima and Imahori). Int. J. Syst. Bacteriol. 45:495-499. 